\title{
SANSKRITIZATION IN THE HINDU TEMPLES OF WEST MALAYSIA
}

\author{
R. RAJOO
}

M.N. Srinivas (1964:30) says that as Sanskritization takes place local and parochial deities, customs and beliefs are dropped by the changing group and more universal patterns of deities, beliefs, etc., are adopted. In the field of religion and rituals the deities of the old order who are parochial, female, who require blood offerings and who are worshipped by lower castes and also served by non-Brahminic priests, are dropped and deities of Hindu pantheon, mainly male deities are absorbed. With this, not only the deities and the priests are changed but also the entire procedure of ritual activities, worship and offerings, is also changed. This change takes place gradually and in almost all aspects of life. This, however, is only partially true. While there are instances where local deities, customs and beliefs are dropped as a result of Sanskritization, on the other hand, there are also instances where local deities, including female, are Sanskritised and elevated to the status of Hindu gods and goddesses. These processes have been identified as universalization and parochialization by McKim Marriott (1955:171-222). In this paper an attempt is made to examine the latter process at work in the Hindu temples in West Malaysia.

\section{Indians in West Malaysia}

Indians form about 10.5 per cent (or approximately 1,200,000) of the total population of West Malaysia. They constitute the third largest ethnic group after the Malays and the Chinese. The majority of these Indians are the descendants of the Indian immigrants who came to the then Malaya during the later part of the nineteenth century and the early part of the twentieth century under the British rule. The bulk of the Indian immigrants were Tamils from South India who were chiefly brought to work in the plantations. Others included Telugus and Malayalis from South India, North Indians and Tamils from Sri Lanka. About 80.0 per cent of the Indians, including the Sri Lankan Tamils, are Hindus.

\section{Characteristics of Hinduism in West Malaysia}

The dominant form of Hinduism practised in West Malaysia is that of South Indian Hinduism, especially that of the Tamils from South India and Sri Lanka. This is reflected in the large number of tempels and their architecture, the types of deities with their local names, festival and so forth. This does not mean that Hinduism practised by other subgroups like Malayalis, Telugus and North Indians 
is very different from Hinduism practised by the Tamils. Indeed, there are crosscutting ties and common strands between them in religious practices. Nevertheless, the differences between them are significant enough. For instance, the North Indians have a strong orientation towards the Védic tradition; the Telugus towards the Vaișnavite sect of Hinduism; the South Indian and Sri Lankan Tamils towards the Tamil Śaivite sect.

The South Indian Hinduism, however, is in no way a homogeneous one. Within it there are important differences. These differences are found in the types of deities worshipped, shrines and temples, modes of worship, domestic rites and lifestyles associated with distinct social groups. Based on these differences, the Hindu shrines and temples in West Malaysia may be classified under the following categories:

\section{Ägamic temples}

First, there are those large temples of Śiva, Gaṇēśa, Subrahmanya, Vịṇu and Māriyamman. These temples are said to have been built according to Ágamic ${ }^{1}$ rules and where worship is held according to these rules, but with some modification and adaptation to local needs and facilities available. These temples have been built by temple architects (sthapatis) hired from Tamil Nadu, South India and have been dedicated according to the rituals called piratishtai or installation of the images of deities, Kumbabishèkam or consecration of the sacred vessel placed above the main shrine and mandaläbishēkam, that is, consecration of the temple through special rites for 40 days. These are complicated rituals stipulated in the Ägamas which can only be done by trained temple ritual specialists-cumpriests called kurukkal (a Śaivite priest) or Pațtar (a Vaișnavite priest), who also serves as priest in these temples. But in some of these temples there are also the Smartha Brahmins who serve as priests. Traditionally, a Smartha Brahmin's role is that of a domestic ritual specialist (Purobita). However, since in Malaysia there are difficulties in getting a Kurukkal or Patțar, often a Smartha Brahmin has become a substitute. The Kurukkal and Pațar are also Brahmins but unlike the Smarthas, they have specifically been trained as temple priests and have been initiated (given tiksha) by the Śaiva and Vaisnnava Accāriyārs (religious teachers). They also follow strict rules of purity and impurity.

In these temples, the daily $p \bar{u} j \bar{a} s$ are performed three times a day, that is, in the morning, noon and evening. The pujas ${ }^{2}$ are accompanied by the chanting of Sanskrit mantras (incantations), the singing of devotional hymns from Tamil sacred texts called Têväram, Tiruvācakam and other similar works, and the playing of the traditional temple band called natasvaram by specialists hired for the purpose.

\footnotetext{
${ }^{1}$ The term is derived from the word Agamas. The Agamas are the authoritative works dealing with temple rituals and worship.

${ }^{2}$ Ritual worship.
} 
These temples usually attract a larger participation of devotees numbering from about 100 to 200, especially on Fridays. Each of these temples celebrates an annual festival on a grand scale, but, in addition, observes all other major Hindu calendrical festivals in the form of special püjās (Vis $\bar{e} s a p \bar{u} j \bar{a} s$ ). Devotees come to these temples not only to participate in the $p \bar{u} j \bar{a} s$, but also to perform a private worship called arcanai. Further, the priests also perform special ritual worship called abishêkam upon request by devotees who pay a special fee.

For the Hindus these temples stand as the embodiment of the Great Tradition Hinduism. However, these temples are fewer in number and are maintained by the urban upper and middle class Hindus living in major towns and cities. Some of these temples are maintained by the Chettiyārs (a traditional money-lending caste from Tamil Nadu) and the Sri Lankan Tamils. Although these temples are open to public worship, that is, for all classes and groups, due to the sophistication with which these temples function they appear somewhat foreign and distant to the majority of the Hindu masses who are less educated and less sophisticated.

\section{Temples of Female 'Village' Deities}

The second category of temples are those dedicated to female deities like Māriyamman and Kāliyamman. The most popular of these, however, is Māriyamman. In South India this deity is traditionally associated with the agrarian society and thus has been known as a village deity. In West Malaysia almost in every estate and town there is a temple for this deity, and her worship is invariably identified with the lower working class Hindus, but the worship of this deity is not uncommon among others. However, the upper class Hindus have very rarely built temples for the deity. Traditionally the deity has been worshipped for the cure of certain diseases like small-pox, cholera, chicken-pox, etc. This practice continues to persist in West Malaysia, where the Hindus specifically worship her in association with chicken-pox, mumps and so forth.

Worship centring round this category of temples has its own distinct features. In these temples, although there may be elements of Ägamik worship, it is predominantly non-Ägamic in nature. For instance, many of these temples have not been built according to strict $\bar{A}$ gamic rules; the image is usually made of cement in contrast to Ägamic temples where the images are made of black stone or karuinkal.

The priests are often part-time $p \bar{u} j \bar{a} r i s$ (or $p \bar{u} c \bar{a} r i s$ ) and only occasinonally are Panțārams. The püjāris are in general those who do not have any formal training in conducting temple rituals. They hardly observe any rules of ritual purity and occupy a very low position in the Hindu priestly hierarchy and are never hired in the A gamic temples. The Pantārams, on the other hand, are caste priests who stand in between the Brahminic priests and the püjäris. Traditionally they performed $p \bar{u} j \bar{a} s$ in temples of the village deities in which the Brahminic priests may not perform $p \bar{u} j \overline{a s}$. 
The daily pujās conducted in these temples are rather simple and are not accompanied by the chanting of Sanskrit mantras or the singing of Tamil devotional hymns. The number of devotees attending these pījoss is rather minimal. However, in each of these temples there is an annual festival which is celebrated on a grand scale for about three days. During the festival the devotees take a keen interest in taking part in the celebration. Though many of the rituals observed during the festival are also found in the Ägamic temples, yet there are others which are not found in the latter. These include the ritual of asking the deity to 'descend' upon a devotee in order to have direct communication with her and, firewalking. Moreover, in many of these temples, on the last day of the festival a goat or fowl is slaughtered to appease the deity. Again, self immolation of the body through piercing skewers into the body, trance and dancing too constitute important features during the celebration. These various features make worship associated with these temples a particular type and different from worship associated with the Agamic temples. Since this form of worship is predominantly found among the less educated Hindu masses, the upper class Hindus make a clear distinction from their mode of worship from that of the lower classes of Hindus.

\section{Temples of Guardian Deities}

Finally, there is the third category of shrines and temples existing for another class of deities known as guardian deities. The most popular of these deities are Muñisvaran and Muniyāntị. These deities are non-Ägamic and local in nature. The temples of these deities are usually small in size and made up of plank and mud walls and zinc roofs. The images are made of cement or clay. Very often they are found in settlement boundaries and way-sides. Besides, their images are also found in the temple compounds of the female 'village' deities like Māriyamman and Kaliyamman. Functionally these masculine deities are said to ward off evil spirits coming to attack their devotees. They are benevolent if propitiated, but would not hesitate to inflict punishment if ignored. These are worshipped by offering animal sacrifice by their devotees and are served by part-time $p \bar{u} j \bar{a} r i s$. The mode of worship in these shrines and temples is thus said to be non- $\bar{A}$ gamic.

The position of these deities remains somewhat ambiguous among the Hindus in West Malaysia. Independent temples of these deities are usually found among lower class Hindus, but they also occupy an important place in private worship among the others. Yet the public nature of the worship of these deities is by and large associated with the lower class Hindus.

\section{Transformation of non-Āgamic temples into Āgamic temples}

In the foregoing discussion, we noted a very general classification of aspects of Hinduism associated with temple worship and its correlation with specific 
social strata of the Hindu society in West Malaysia. It must be stressed here that there are bound to be exceptions to these classifications but these exceptions must be seen in the light of the dynamics of a changing society and the diffused nature of Hinduism.

An interesting development in Hinduism in West Malaysia is that the shrines and temples of the second and third categories are gradually transforming into temples of the A $\overline{g a m i c}$ type in varying degrees. In this connection, temples dedicated to Măriyamman, Kāliyamman and Muniśsaran draw our attention in particular. A few instances of these temples may be cited here:

\section{Ritual change in temples of female 'village' deities}

The Śri Mahā Māriyamman temple in High Street, Kuala Lumpur, is today acclaimed to be one of the largest Hindu temples in West Malaysia. It is managed by an association known as the Śri Maha Māriyamman Temple Dēvastānam comprising South Indian Tamils of non-Brahmin castes. (The Chețtiyārs and Sri Lankan Tamils have no direct participation in the management). The association also manages a popular Ganêsa temple and the Sri Subrahmanya temple at Batu Caves in Kuala Lumpur. The Śri Mahā Māriyamman temple itself was started in the 1870s by one Thambusamy Pillai, then a well-known Tamil in Kuala Lumpur. Unfortunately no account as to the mode of worship - whether A gamic or nonAgamic and as to when the temple was started, is not available now. However, according to oral tradition, it was started as a miniature temple in the centre of the city and in all probability ritual worship was both Agamic and non-Āgamic. The temple gradually expanded and became a community temple as more and more Hindu devotees took a keen interest in it. As the financial position of the temple improved, it also came under the strong influence of Agamization (or Sanskritization) by adopting A $g a m i c$ mode of worship. In this process Brahmin priests were hired from South India to perform $p \bar{u} \bar{a} s$ in the temple. In the 1970s, temple architects (sthapatis) were brought from South India to build the temple's gateway (gopuram), and also to rennovate the temple. Besides, the Dévastanam undertakes several Hindu religious activities including conducting religious classes and organising annual conference of the Śaivite devotional works (Tirumuraikal). Today the temple has thus become a model Âgamic temple for the non-Āgamic Māriyamman and Kạliyamman temples in West Malaysia.

There are several other Māriyamman temples in other major towns which have undergone a similar process of change and are being attended by even the upper class Hindus. In this transformation the deity Māriyamman is identified with the Pan Indian goddess, Śakti and is thus given all the attributes of the Ägamic deities. The Rāja Rājeśsariyamman temple in Ulu Klang in Kuala Lumpur is a case of a Māriyamman temple which has undergone a similar change in recent years. Until the present temple was built in 1977, there was a miniature Māriyamman temple 
in its place. This temple was maintained by a group of Hindu workers living in the locality. During the last two decades the area came to be converted into a modern housing estate. Some middle class Hindus who came to live in this housing estate felt the need for a Hindu temple to serve the Hindu community there. They decided to rennovate the existing Māriyamman temple. With the help of the leaders of the Malaysian Indian Congress (M.I.C.), they acquired the piece of land on which the Māriyamman temple stood and some financial aid from the government to rebuild a new temple. Temple architects from Tamil Nadu, South India, were brought and a new temple was erected according to Agamic principles. While the temple was under construction, the question of naming the temple became an important concern. Many felt that there were already far too many Māriyamman temples in the country and therefore the temple should be known by a different name which is reflective of the higher Hindu tradition. The underlying sentiment in this concern was that most Māriyamman temples in the country by and large reflected the non-Agamic Hindu tradition which was also identified synonymously with the lower class Hindus. Consequently, the temple was named as the Śri Raja Rajjeśvariyamman temple - a name which resembles those of the major temples of the Ägamic tradition in South India. At present this temple conducts $\bar{p} \bar{u} \overline{a s}$ according to the Agamic rules with the help of two Kurukkal hired from Tamil Nadu, South India. The temple also functions as a centre of the Indian cultural performances of Indian classical (karnatic) music and dance (bbarata-natyam) which are considered as an integral part of Great Tradition Hinduism.

Many shrines and temples dedicated to the deity Kāli or Kāliyamman too are currently undergoing this kind of change. The Śri Mahā Kạ̣iyamman temple next to the hospital workers' quarters near the General Hospital in Kuala Lumpur is an example of this. This temple was founded first as a shrine by a young Tamil girl who became a medium around the age of 20 . She started the shrine in order to help her clients by going into trance. Her father, a labourer in the General Hospital, helped her to put up the shrine as the latter was doing a service to the people with the grace of goddess Kăli. The clients who benefited through the medium made generous contributions which was later used to build a temple in honour of the goddess. It became a public place of worship for the Hindu devotees in the locality, while the medium continued to play her role in it. One of her assistants, a young male, became the pūjäri in the temple. Gradually, many Ägamic elements were incorporated into the mode of worship in the temple. For instance, during the $p \bar{u} j \overline{a s}$ young children were made to sing Tamil devotional hymns. Along with the annual festival celebrated in honour of the goddess, many special püjas were also included in accordance with the ritual calendar of the major Hindu temples. In 1974 local singers and misicians were invited to give cultural performances during the annual festival. During the festival goats were slaughtered; however, the medium and the püjarri claimed that the slaughtering was given to Munis ${ }^{-}$ 
varan, the guardian deity in the temple. As such, at the time of the slaughtering the image of Kạli and pictographs of other Ägamic deities were screened off.

Another interesting feature of the medium's act was that she claimed to have the grace of all the gods and goddesses of higher Hinduism. This was symbolically enacted by her at the time she went in trance. First, she portrayed herself like goddess Käli, then as the elephant-faced Gaṇeśa, then Națaräja (Siva), then Kriṣna and so forth. Throughout this enactment the devotees and clients held their palms in prostration. Although the medium did the enactment perhaps to impress upon the audience, what is of particular interest here is that there is a clear attempt to synthesise Ägamic (or Sanskritic) Hinduism with non-Āgamic (or non-Sanskritic) practices.

\section{Ritual change in temples of the guardian deity, Munísvaran}

Likewise, many shrines and temples dedicated to the guardian deity Muniśvaran too have been subjected to a similar change. We have noted briefly above the attributes and traditional mode of worship associated with this deity. Now, whenever such a change occurs in a Munisvaran temple, the deity is identified as Siva, the Pan Indian Ägamic or Sanskritic god. In many instances the, pūjāris serving in Munisvaran temples claim that the deity is none other than Siva and that the animal sacrifice given in his shrine is actually given in honour of another supernatural, called Munnatiyān whose role is that of a 'door-keeper'. This supernatural is often represented in front of the shrines of Munisvaran in brick-stones or triads. In temples where Muniśsaran is equated with Siva, the main shrine is screened off at the time of the slaughtering of the animal. However, this seems to be a situation of change rather than a rule because there are instances where the deity Muniśvaran is given animal sacrifice.

An instance of a Muñiśvaran temple becoming Āgamic was witnessed by the writer in 1972 at the army camp in Sungei Besi, Kuala Lumpur. Until then this guardian deity was housed under a wooden roof surrounded by clay walls. The image of the deity was made of cement. Worship in the shrine was predominantly characterised by non-Āgamic practices. At the beginning of 1972 , a few individuals took some interest in the shrine and decided to put up a temple proper. As the temple was being constructed they also decided to change the form of worship following the Âgamic temples in Kuala Lumpur. They hired a Śaivite Kurukkal from a major temple in Kuala Lumpur who performed the rituals called piratishțai, Kumbābishēkam and Mandalābishēkam. There were two images, one Muniśsvaran and the other Chamuntiśvari, brought from South India for installation in the temple. According to the Kurukkal, he treated the two as the personifications of Siva and Sakti, respectively, and thus accorded them Ägamic rites.

The Muniśsvaran temple along the Sri Raja Muda road in Kuala Lumpur is undergoing a similar process of change. It was started as a shrine by an individual 
near his house in the 1950 s. Soon it attracted Hindu workers staying nearby and thus it evolved into a community temple. The man who erected the shrine became the püjari and worship was held following the non-Ägamic tradition. However, the coming of two important personalities into the administration of the temple brought some significant changes. One of them was a Tamil who lived nearby and the other a North Indian Hindu businessman. The two were until then actively involved in local M.I.C. politics. Both had strong leadership aspirations. The Tamil wanted to serve the poor Tamils in the locality through the Muniśvaran temple. Thus he became the secretary of the temple's managment committee. At first he wanted to raise the status of the temple by introducing the Ägamic mode of worship and other welfare activities in the temple. He stopped offering of animal sacrifice in the temple. With the help of the North Indian, who also happened to be a social worker, he obtained aids through the local political representatives. With this, he expanded the temple and introduced sewing and religious classes for the Hindu children in the neighbourhood. Other activities such as annual sports were also introduced. He undertook to bring these changes because he found that only the poor Hindus attended the temple. The educated and well-to-do Indians living nearby would not attend the temple because they held the Muniśvaran temple in low esteem. He even thought that the latter regarded the deity as the deity of the poorer Hindus. He said that his view was shared by the North Indian too. Both decided to approach the government to acquire the piece of land on which the Muñiśvaran temple stood and also to obtain financial aid to put up a new temple. They have succeeded in both and according to a newspaper report they hoped to put up the biggest Muniśvaran temple in West Malaysia. When this is done, it can be expected that the temple would undergo a large-scale Ágamization. At the moment only a püjāri is performing the rituals in the temple. But animal sacrifice has been stopped. On the other hand, the celebration of Siva-Rāttiri - a festival associated with the worship of Siva has been adopted.

It would also be interesting to note how the two individuals have also been responsible to bring about related changes in other Muníśnaran temples throughout West Malaysia. In 1974 they organised a conference of Muniśvaran and Kạliyamman temples in the country. Representatives of some 37 Munisvaran and Kạliyamman temples (predominantly from the former) attended the conference. National-level M.I.C. leaders and representatives of various Hindu bodies in the country were also invited to attend. One of the resolutions passed at the conference declared, that the deity Muniśvaran was, indeed, a manifestation of the Āgamic god Siva, and, as such, offerings of animal sacrifice and other nonÄgamic practices should be discontinued in Muniś' of the conference were reported in the local Tamil press and thus the conference, indeed, made considerable impact on the local Muniśvaran temples. 


\section{Conclusion}

The kind of ritual change taking place in the Hindu temples in West Malaysia is, indeed, identical to what Srinivas called Sanskritization. In Indian society Sanskritization is seen as a specific kind of cultural mobility through which groups who have hitherto remained fragmented, become integrated by raising their cultural status. Srinivas stresses that this cultural mobility takes place within the caste system (1968:6). Thus, lower castes rise to the cultural status of higher castes as they adopt the religious practices, customs and life-styles of higher castes. He also argued later that a change in the educational, occupational and socio-economic statuses is a precondition for Sanskritization to take place. Thus, Sanskritization is closely linked with upward mobility. That is, when groups occupying lower socio-economic position move up, they also want to identify with a better cultural status following those groups which already occupy such a position with a particular form of cultural correlate. In this case, the higher castes become a reference model for the lower castes since they occupy a high position in the prestige scale of the Hindu social hierarchy.

Ritual change in the Hindu temples of West Malaysia, however, shows some interesting features. First, it seems that it would be misleading to view the kind of ritual change taking place in the Hindu temples which may be called A tion or Sanskritization in terms of the caste system. Caste may operate in particular contexts, but it does not become a general rule in the kind of ritual process that is going on. There are several reasons for this: The caste structure here does not reflect that of the caste structure in India. There is no strong Brahminical influence here. Neither is there a dominant influence of the non-Brahmin orthodox castes such as the Vella alas (from South India). The absence of this orthodox influence and other factors like migration and working in an industrial economy have eroded many of the rigid norms of caste. This is especially so among the second and third generation Malaysian-born Indians who form the bulk of the Malaysian Indian population. Again, most of the ritual change discussed in this paper mainly takes place in the urban setting where Indians are dispersed all over. Caste, as McKim Marriott (1955:191) notes, can only function effectively in "small packages" (in village communities). In a rapidly changing complex urban situation, other criteria become more important for social interaction. Thus it is not uncommon to find in most Hindu temples of West Malaysia the different subcastes and even subethnic groups taking part together not only in worship, but also in temple organisation.

It would seem therefore that it is more appropriate to talk of class as an important factor to explain the kind of ritual change taking place in the Hindu temples of West Malaysia. For instance, when a group occupying a lower social position āgamizes' its temple, it does so by following the more Ägamic temples run by the upper class Hindus. It is true that some of these temples are run by 
the Chețtiyārs, a traditional Vaishya caste, and the Sri Lankan Tamils who may be made up of Veḷalas. However, these groups are often not regarded as specific castes in any rigid sense by the upwardly mobile groups, but as specific social groups or categories and classes occupying higher social statuses. In India, as Srinivas shows, the lower castes Sanskritize in order to claim a higher caste status based on the dominant caste of the locality by using the label of that caste to which identity and equality of status is desired. It is not denied here that there are no occurrences of this kind of 'upcasteing' or 'caste climbing'. For instance, an Ādi Drāvida may claim a higher status as a Gavanțan (a South Indian non-Brahmin middle-ranking or Veḷāạ caste) just as a Pațaiyācci may claim to be a Vanniya (both are non-Brahmin agricultural castes in South India) while the latter that of a Gavanțan. ${ }^{2}$ But Āgamization in the Hindu temples of West Malaysia is not solely based on this kind of 'caste-climbing'. In West Malaysia rigid division of caste hierarchy between the non-Brahmin castes and the Ādi-Drāvidas has been broken down and the social distance narrowed as a result of the rising socio-economic status of the latter. Westernization and secularization among all castes in the domestic sphere have further weakened caste distinctions on the basis of lifestyles. Thus, Āgamization of a Hindu temple is effected both by non-Brahmin castes and Ādi-Drāidas attending the same temple.

Secondly, the influence of ethnic identity is also an important factor when lower classes try to raise their cultural identity through Ägamization in the Hindu temples of West Malaysia. For, when the lower classes (which include both nonBrahmins and Ādi-Drāvidas) do so, they not only want to be identified as social equals by the upper class Hindus but also as high status Indians by other ethnic groups, that is, the Malays and the Chinese. This is evident from the newly urbanising Hindus living on the fringes as well as in the middle of urban centres who are much concerned about their cultural identity in a multi-ethnic environment. The role of the various Hindu movements in West Malaysia, whose leadership is mainly drawn from the middle class Hindus in trying to change the cultural status of the Hindu masses through teaching higher or Sanskritic Hinduism, also supports this point.

Finally, the process of Āgamization among Hindus in West Malaysia does not often result in the dropping of local deities but they are incorporated by giving new attributes according to Hindu pantheon gods and goddesses and their status is raised to that of the latter as has been shown in this article.

\footnotetext{
3 Among the lower class Tamils in West Malaysia, the Gavantan subcaste is often taken to be the 'Dominant' caste. In the traditional Indian society a dominant caste is the one with economic, ritual and political power. For a further discussion on this, see F.G. Bailey, 1966, pp. 257-263.
} 


\section{REFERENCES}

BAILEY, F.G. Tribe, Caste and Nation. Manchester: The University of Manchester Press, 1966.

MARRIOTT, McKim. "Little Communities in an Indigenous Civilization," in, McKim Marriot (ed.), Village

India: Studies in the Little Community (Chicago: The University of Chicago Press), 1955, pp. 171-222. SRINIVAS, M.N. Religion and Society among the Coorgs of South India. Bombay: Asia Publications, 1964. Social Change in Modern India. Berkeley and Los Angeles: University of California Press, 1968. 